\title{
An Empirical Investigation on the Validity of Linder Hypothesis for Manufacturing Exports from Turkey to Eurozone Countries
}

\author{
Dr. Emrah Eray Akça (Çukurova University, Turkey) \\ Prof. Dr. Harun Bal (Çukurova University, Turkey)
}

\begin{abstract}
Linder's hypothesis expresses that non-homogenous manufacturing trade has been determined by the consumers' tastes and preferences rather than production cost differences between countries. Also, it is claimed that the consumers' tastes and preferences relate positively to the level of per capita income of the relevant country. Accordingly, the country pairs which have similar levels of per capita income trade each other more than other country pairs.

This study analyses the validity of the Linder hypothesis in manufacturing exports from Turkey to 19 Eurozone countries for the period of 2002-2018. In compliance with the bilateral trade structure, an augmented gravity model is constructed with variables representing the Linder effect. Generally, convergence between country pairs in terms of per capita income is taken while testing the Linder hypothesis into account. Therefore, while testing the Linder hypothesis, the study considers per capita gross domestic product differences between Turkey and Eurozone countries. Besides, as a more salient and efficient tool, a similarity index representing the Linder effect is constructed. By doing so, whether the Linder hypothesis is valid or not can be demonstrated more robustly.

Empirical results prove the existence of the Linder effect for Turkey's manufacturing exports to Eurozone countries. In other words, on the contrary of factor endowment differences, demand similarities between Turkey and Eurozone countries encourage this type of trade. In this regard, the exporters who target more manufacturing exports should monitor the course of consumer behaviors and adapt their product structure according to consumer's tastes and preferences in Eurozone countries.
\end{abstract}

\section{Introduction}

International trade flows have been dominantly explained by traditional trade theories, i.e., theories of absolute advantages and comparative advantages and factor endowment theory focusing on the differences of production costs that result from factor endowment differences between countries. Accordingly, the countries should specialize in the production of goods they produce with the lowest costs, and then export them to the rest of the world. Other goods that relatively involve high-production costs should be imported from the rest of the world. In this way, all the countries would benefit from international trade and overall, the world welfare increase. However, traditional trade theories have strict presumes such as constant return to scale and homogenous tradable goods. While these presumes generally hold the ex-post economic activities till the second world war, after this time, they have beginning to lose their validities because of reducing factor endowment differences between countries, rising similarity rate in factor intensities of goods, showing up intra-industry trade, and increasing sensitivity of trade flows to income changes. Thus, in past, while expecting relatively more trade between different country pairs economically, nowadays more trade is expected between similar countries economically. This expectation, in fact, markedly has come to light following the seminal study of Linder (1961) who developed the theory of similarity in preferences.

The theory of similarity in preferences (or overlapping demand) is one of the alternative trade theories developed in the 1960s. On the contrary other alternative trade theories such as technological gap, skilled labor, and product cycle, the theory of similarity in preferences approaches the demand-side to trade flows. Therefore, this theory which bases on increasing returns to scale and differentiated products is evaluated as the first trade theory considering demand structures of countries. From these respects, the theory of similarity in preferences is compatible with arguments of imperfect trade theories like scale economies and product differentiation (Arnon and Weinblatt, 1998). To say more clearly, the theory of similarity in preferences explains the trade of nonhomogenous manufacturing goods by consumers' tastes and preferences rather than differences in production costs. According to the theory of similarity in preferences, any country produces goods to primarily satisfy the domestic demand. The country specializing in these goods over time exports them to other countries where home country and destination have similar tastes and preferences (this is called representative demand) through increasing returns to scale. Hence, trade intensity between countries having similar tastes and preferences would be more compared with other country pairs. This argument is supported with actual trade developments given especially the largest portion of global trade is taken place amongst developed countries and increasing share of intra-industry trade on the global scale.

Trade intensity mentioned in Linder's hypothesis doesn't mean simply the trade volume. Accordingly, since trade volume is dominantly directed by the sizes of trade partners, country sizes should be eliminated. For this, Linder (1961) investigated the demand structures of countries and calculated their propensities to import from each 
other and concluded that the most important determinant of the demand structure of any country is the level of the average income of that country. In this case, the similarity of countries in terms of average income means the similarity of countries in terms of demand structure. Linder (1961) also expressed that median incomes have more representative power than the average income in particularly the countries where skewness of income distribution is explicit. Yet, from the statistical and empirical points, finding the median incomes is too difficult. Therefore, per capita income, i.e., arithmetic mean, is considered as an indicator of the demand structure. Eventually, demand structure reflecting consumers' tastes and preferences associated positively with their per capita income levels. In this way, the level of per capita income in any country is a driving force of tastes and preferences in that country. So, in the first stage, the tastes and preferences of consumers in any country depending upon their per capita income direct the demand of goods. In the second stage, this demand leads to the production of these goods by domestic firms. In the last stage, these produced goods are exported to other countries where there are similar levels of per capita income. Hereby, produced goods in any country reflect the per capita income of that country. Additionally, here is proposed that per capita income in any country is determined by the stock of capital goods in that country (Atik, 2006).

This study questions the potential existence of the Linder hypothesis in Turkey's manufacturing exports to Eurozone countries over the period of 2002-2018. The rest of the study is organized as follows: Section two embodies some statistics regarding Turkey's foreign trade developments by especially focusing on trade relations between Turkey and Eurozone countries. While section three is dedicated to empirical literature review investigating the Linder hypothesis for Turkey, section four introduces dataset and econometric model. After providing the empirical results in section five, the study ends up with section six where the conclusion and remarks are given a place.

\section{Overall View of Trade Developments of Turkey}

Liberalizing its economy at the beginning of the 1980s, Turkey has made progress in merchandise trade in terms of both exports and imports. However, the most striking progress has been observed post-2000s albeit some structural breaks like the 2007-2008 global financial crises and devastating COVID-19 pandemic. In Figure 1, the developments of export and import in Turkey are illustrated from 1980 to 2020. While Turkey's merchandise exports and imports were approximately 28 and 55 billion dollars, respectively, in 2000, these values reached 170 and 220 billion dollars, respectively, in 2020. Thus, Turkey's trade deficit was 50 billion dollars in 2020. In the same year, the export and import shares of Turkey in the world were $0.96 \%$ and $1.24 \%$. COVID-19 pandemic has been affecting the merchandise trade. Accordingly, while exports grew just by $2.1 \%$ in 2019 , imports shrank by $9.1 \%$ in the same year. Contrary to this, while downsizing in exports was observed by $6.3 \%$ in 2020 , imports grew by $4.3 \%$ in the same year. By the general sights, although the increasing trade volume of Turkey in the $2000 \mathrm{~s}$, decreasing terms of trade is drawn attention in the same period.

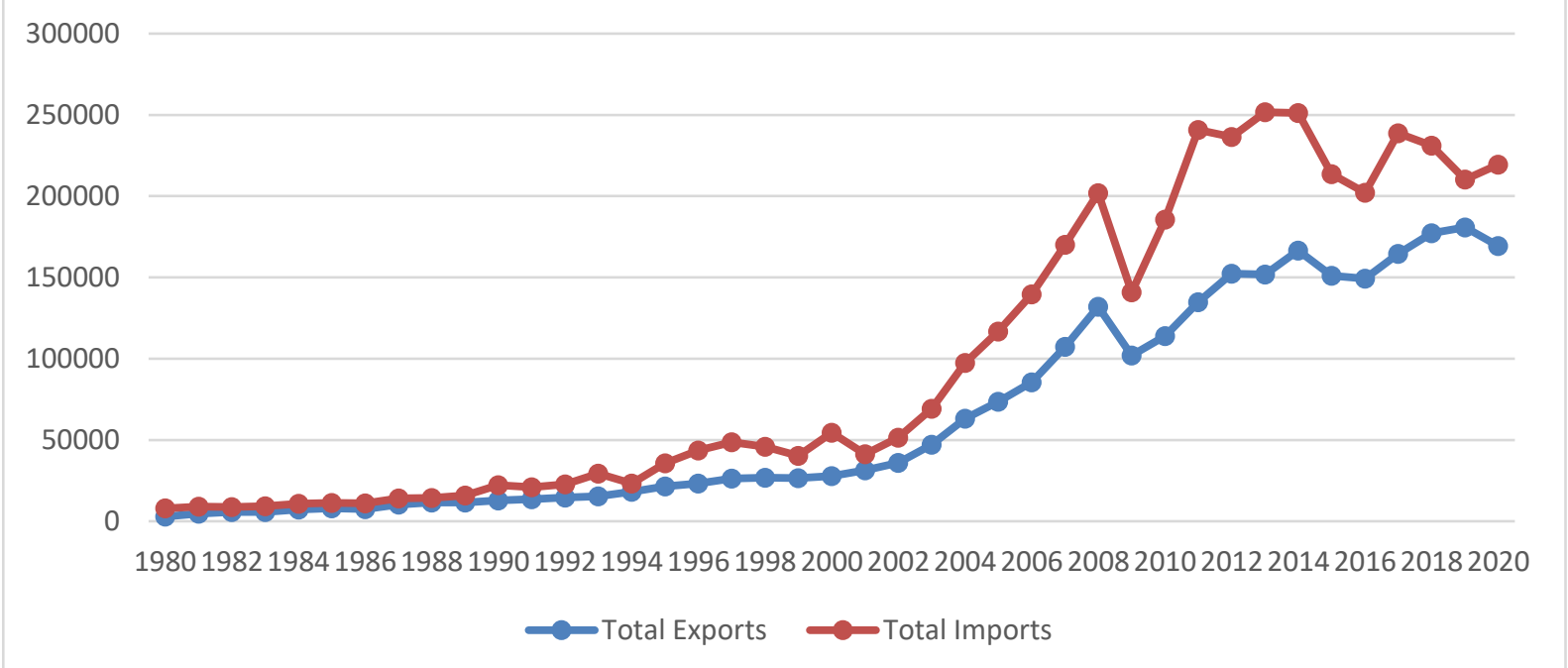

Figure 1. Total Export and Import Developments of Turkey Source: UNCTAD (2021). Note. The trade values are in million US dollars at current prices.

In parallel with increasing trade volume over time, product compositions that Turkey exports and imports have shifted from labor-intensive products to capital-intensive products as well. In this regard, product concentration and diversification indexes may guide our insights. The product concentration index indicates to what extent exports and imports of any country concentrated on a few products rather than being distributed in a more homogenous manner among several products. Product diversification index indicates the degree to which the product structure of exports or imports of any country differs from the overall trade pattern of the world. Figure 2 
indicates the developments in Turkey in terms of concentration and diversification by product group for both exports and imports from 1995 to 2019 . Accordingly, the product structure of exports diverges from those of the rest of the world over time, whereas the product structure of imports relatively converges to those of the rest of the world. While the export concentration index did not change significantly, the import concentration index rose to a moderate extent.

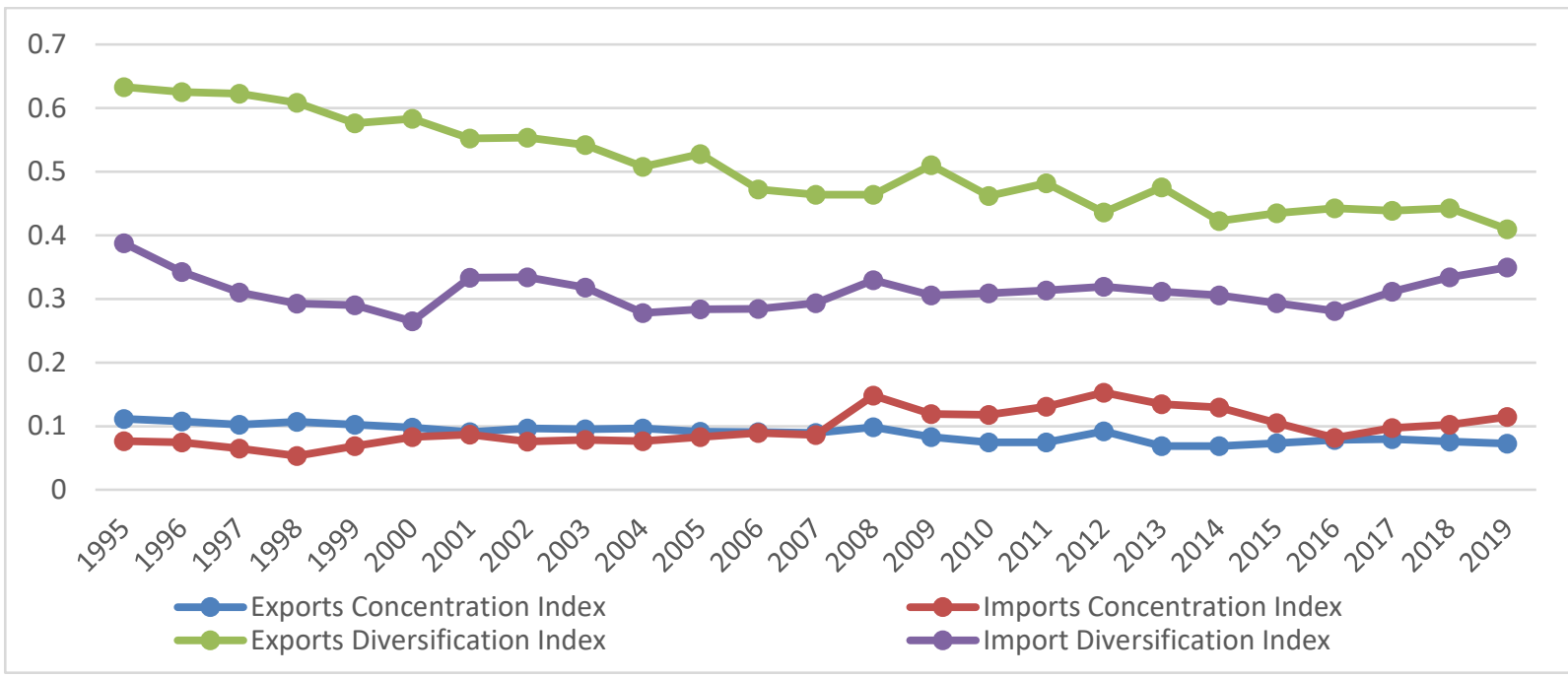

Figure 2. Concentration and Diversification Indicators by Product Group in Exports and Imports of Turkey Source: UNCTAD (2021)

When researched the geographical distribution of Turkey's merchandise trade, European Union (EU) countries have been continuously leading partners in terms of especially export flows. Among the EU countries, Eurozone countries account for the largest part of the merchandise trade of Turkey. Overall, Turkey's exports to Eurozone countries correspond to almost $35 \%$ of its total exports, and its imports from them correspond to almost $27 \%$ of its total imports, respectively, in 2018. In Table 1, the merchandise trade of Turkey with Eurozone countries is shown for some periods.

\begin{tabular}{|l|r|r|r|r|r|r|}
\hline & \multicolumn{3}{|c|}{ Exports } & \multicolumn{3}{c|}{ Imports } \\
\hline Trade Partners & \multicolumn{1}{|c|}{$\mathbf{2 0 0 2}$} & \multicolumn{1}{|c|}{$\mathbf{2 0 1 0}$} & \multicolumn{1}{c|}{$\mathbf{2 0 1 8}$} & \multicolumn{1}{c|}{$\mathbf{2 0 0 2}$} & \multicolumn{1}{c|}{$\mathbf{1 0 1 0}$} & \multicolumn{1}{c|}{$\mathbf{2 0 1 8}$} \\
\hline Austria & 363.010 & 835.181 & 1.160 .600 & 587.374 & 1.439 .448 & 1.494 .566 \\
\hline Belgium & 689.352 & 1.960 .441 & 3.952 .510 & 1.147 .102 & 3.213 .606 & 3.571 .420 \\
\hline Cyprus & 217.279 & 975.768 & 1.226 .471 & 20.062 & 58.468 & 67.834 \\
\hline Estonia & 18.058 & 90.324 & 91.736 & 1.177 & 146.192 & 220.198 \\
\hline Finland & 135.499 & 296.774 & 339.194 & 371.997 & 1.115 .496 & 984.019 \\
\hline France & 2.123 .543 & 6.054 .499 & 7.296 .041 & 3.047 .501 & 8.176 .600 & 7.412 .853 \\
\hline Germany & 5.835 .207 & 11.479 .066 & 16.144 .215 & 7.014 .695 & 17.549 .112 & 20.407 .162 \\
\hline Greece & 582.816 & 1.455 .678 & 2.089 .304 & 323.939 & 1.541 .600 & 2.104 .387 \\
\hline Ireland & 181.181 & 339.265 & 754.528 & 476.546 & 873.961 & 889.836 \\
\hline Italy & 2.361 .212 & 6.505 .277 & 9.566 .346 & 4.132 .123 & 10.139 .888 & 10.154 .449 \\
\hline Latvia & 20.247 & 65.958 & 125.690 & 220 & 71.360 & 165.120 \\
\hline Lithuania & 52.660 & 208.277 & 276.110 & 109.547 & 119.165 & 410.412 \\
\hline Luxembourg & 16.460 & 25.758 & 66.683 & 133.069 & 114.342 & 152.433 \\
\hline Malta & 132.453 & 410.433 & 483.436 & 28.279 & 196.156 & 35.948 \\
\hline Netherlands & 1.043 .866 & 2.461 .371 & 4.778 .109 & 1.308 .322 & 3.156 .000 & 3.304 .603 \\
\hline Portugal & 221.784 & 465.228 & 1.109 .641 & 100.604 & 503.658 & 654.350 \\
\hline Slovak Republic & 32.527 & 454.744 & 531.734 & 112.241 & 926.722 & 767.137 \\
\hline Slovenia & 68.864 & 356.502 & 1.430 .317 & 56.997 & 291.314 & 316.898 \\
\hline Spain & 1.115 .226 & 3.536 .247 & 7.710 .440 & 1.388 .799 & 4.840 .127 & 5.492 .394 \\
\hline
\end{tabular}

Table 1. The Merchandise Trade of Turkey with Eurozone Countries. Source: WITS (2021). Note: The trade values are in thousands of US dollars at current prices.

\section{Literature Review}

Following the stimulating study of Linder (1961), many studies have been investigating the relevance of the Linder hypothesis in international trade. In some studies, the cross-country analysis has been considering whilst other ones focusing on only one country's trade dynamics. When investigated the empirical literature on the 
relevance of the Linder hypothesis in trade flows of Turkey, it is observed that the studies are mostly conducted post-2000s. Table 2 illustrates the empirical studies examining the relevance of the Linder hypothesis in the trade flows of Turkey.

\begin{tabular}{|c|c|c|c|c|}
\hline Author(s) & $\begin{array}{l}\text { Country } \\
\text { coverage }\end{array}$ & Timespan & Method & Findings \\
\hline Kohlhagen (1977) & $\begin{array}{l}\text { All trade } \\
\text { partners }\end{array}$ & 1964-1968 & $\begin{array}{l}\text { Ordinary least } \\
\text { squares (OLS) }\end{array}$ & $\begin{array}{l}\text { There exists the Linder effect in Turkey's } \\
\text { imports. }\end{array}$ \\
\hline Hallak (2004) & 60 countries & 1995 & $\begin{array}{l}\text { Cross-section } \\
\text { analysis }\end{array}$ & $\begin{array}{l}\text { Linder hypothesis is supported at sectoral } \\
\text { export, but not at the aggregate level. }\end{array}$ \\
\hline Atik (2006) & $\begin{array}{l}\text { Main trade } \\
\text { partners }\end{array}$ & $1990-2000$ & $\begin{array}{l}\text { Fixed effects } \\
\text { estimator }\end{array}$ & $\begin{array}{l}\text { Linder hypothesis was found to be suitable } \\
\text { for Turkey's imports }\end{array}$ \\
\hline $\begin{array}{l}\text { Bilgin, et. al, } \\
(2011)\end{array}$ & United States & 1989-2008 & $\begin{array}{l}\text { Fixed effects } \\
\text { estimator }\end{array}$ & $\begin{array}{l}\text { Linder effect was found to be valid for } \\
\text { Turkish homemade carpet exports to the } \\
\text { United States. }\end{array}$ \\
\hline $\begin{array}{l}\text { Erkekoğlu and } \\
\text { Arıç (2013) }\end{array}$ & $\begin{array}{l}28 \mathrm{EU} \\
\text { countries }\end{array}$ & $2007-2010$ & Cluster analysis & $\begin{array}{l}\text { Turkey's similarity with EU countries in } \\
\text { terms of competitiveness dynamics has } \\
\text { risen since } 2008 \text {. }\end{array}$ \\
\hline $\begin{array}{l}\text { Saygili and } \\
\text { Manavgat (2014) }\end{array}$ & $\begin{array}{l}30 \text { main } \\
\text { trade } \\
\text { partners }\end{array}$ & $1995-2011$ & $\begin{array}{l}\text { Fixed and random } \\
\text { effects estimators }\end{array}$ & $\begin{array}{l}\text { Linder's hypothesis was found to be } \\
\text { statistically significant and valid for } \\
\text { Turkey's imports, but not for exports. }\end{array}$ \\
\hline Işık (2015) & $\begin{array}{l}19 \text { Eurozone } \\
\text { countries }\end{array}$ & 2001-2013 & $\begin{array}{l}\text { Pooled OLS and } \\
\text { Random effects } \\
\text { estimator }\end{array}$ & $\begin{array}{l}\text { There is not Linder effect on trade between } \\
\text { Turkey and Eurozone countries. }\end{array}$ \\
\hline $\begin{array}{l}\text { Çağlayan-Akay } \\
\text { and Oskonbaeva } \\
(2017)\end{array}$ & $\begin{array}{l}\text { Main trade } \\
\text { partners }\end{array}$ & $2001-2005$ & $\begin{array}{l}\text { Panel Tobit } \\
\text { approach }\end{array}$ & $\begin{array}{l}\text { Linder's hypothesis was found to be } \\
\text { unsuitable for Turkey's export. }\end{array}$ \\
\hline $\begin{array}{l}\text { Y1ldiz and Künü } \\
(2018)\end{array}$ & BRICS & 1996-2016 & $\begin{array}{l}\text { Random effects } \\
\text { estimator }\end{array}$ & $\begin{array}{l}\text { Linder's hypothesis was found to be valid } \\
\text { for Turkish exports, but not valid for } \\
\text { Turkish imports. }\end{array}$ \\
\hline $\begin{array}{l}\text { Yavuzaslan, et. al, } \\
(2018)\end{array}$ & $\begin{array}{l}33 \text { OECD } \\
\text { countries }\end{array}$ & $2002-2016$ & $\begin{array}{l}\text { Random effects } \\
\text { estimator }\end{array}$ & $\begin{array}{l}\text { As Turkey and OECD countries are more } \\
\text { similar economically, Turkey's exports } \\
\text { increase to these countries. }\end{array}$ \\
\hline $\begin{array}{l}\text { Çağlayan-Akay } \\
\text { and Oskonbaeva } \\
(2018)\end{array}$ & $\begin{array}{l}20 \text { OECD } \\
\text { countries }\end{array}$ & 2001-2005 & $\begin{array}{l}\text { Random effects } \\
\text { and Tobit model }\end{array}$ & $\begin{array}{l}\text { There is no significant effect of the Linder } \\
\text { variable on exports of Turkey }\end{array}$ \\
\hline $\begin{array}{l}\text { Maden and } \\
\text { Aljburi (2019) }\end{array}$ & 53 countries & $1990-2016$ & $\begin{array}{l}\text { Pooled OLS and } \\
\text { random effects } \\
\text { estimator }\end{array}$ & $\begin{array}{l}\text { Turkey exports and imports more to the } \\
\text { countries in which they are economically } \\
\text { similar. Namely, the Linder effect is valid } \\
\text { for both Turkey's exports and imports. }\end{array}$ \\
\hline $\begin{array}{l}\text { Erkekoğlu and } \\
\text { Yilmaz (2019) }\end{array}$ & $\begin{array}{l}21 \text { APEC } \\
\text { countries }\end{array}$ & $1997-2016$ & $\begin{array}{l}\text { Fixed effects } \\
\text { estimator }\end{array}$ & $\begin{array}{l}\text { Linder effect was found to be an } \\
\text { encouraging factor of trade volume } \\
\text { between country pairs. }\end{array}$ \\
\hline $\begin{array}{l}\text { Gündüz, et. al, } \\
(2020)\end{array}$ & $\begin{array}{l}\text { Main trade } \\
\text { partners }\end{array}$ & $2002-2017$ & $\begin{array}{l}\text { Driscoll Kraay } \\
\text { estimator }\end{array}$ & $\begin{array}{l}\text { Linder's hypothesis is suitable for Turkey's } \\
\text { cotton exports. }\end{array}$ \\
\hline $\begin{array}{l}\text { Cebeci and } \\
\text { Ghorbani (2020) }\end{array}$ & Iran & $2007-2017$ & $\begin{array}{l}\text { Poisson pseudo } \\
\text { maximum } \\
\text { likelihood }\end{array}$ & $\begin{array}{l}\text { Linder's hypothesis is not valid for imports } \\
\text { from Turkey to Iran, on the contrary, } \\
\text { income differences between them affect } \\
\text { positively Turkey's imports from Iran. }\end{array}$ \\
\hline $\begin{array}{l}\text { Akça and Bal } \\
(2020)\end{array}$ & $\begin{array}{l}30 \text { major } \\
\text { trade } \\
\text { partners }\end{array}$ & $2003-2018$ & $\begin{array}{l}\text { Fixed effects } \\
\text { estimator, } \\
\text { Hausman-Taylor } \\
\text { and Amemiya- } \\
\text { MaCurdy }\end{array}$ & $\begin{array}{l}\text { Linder's hypothesis was not found to be } \\
\text { valid for Turkey's export flows, contrary to } \\
\text { this, exports principally are determined by } \\
\text { relative factor endowment differences } \\
\text { between country pairs. }\end{array}$ \\
\hline
\end{tabular}

Table 2. The Summary of Empirical Literature Examining Linder Hypothesis for Turkey's Trade Flows

\section{Dataset and Econometric Model}

Analyzing the existence of the Linder effect in trade relations of Turkey with Eurozone countries, the study employs the balanced panel data of the 2002-2018 period. This period is chosen since Turkey made notable progress in terms of merchandise trade in that period. The Eurozone countries are Austria, Belgium, Cyprus, 
Estonia, Finland, France, Germany, Greece, Ireland, Italy, Latvia, Lithuania, Luxembourg, Malta, Netherlands, Portugal, Slovak Republic, Slovenia, and Spain. Linder's hypothesis here is analyzed by using the Gravity model which is accepted as a workhorse of international trade analysis. The gravity model application of international trade which was developed by Timbergen (1962) asserts that bilateral trade flows, i.e. one-way trade, are directly proportional with the economic sizes of country pairs and inversely proportional with the distance between them. Thus, to not fall into the bronze medal mistake which was first highlighted by Baldwin and Taglioni (2006), the study considers just export flows from Turkey to Eurozone countries, not average or sum of export and import flows, i.e. trade volume. Besides, the study analyses just manufacturing export flows by excluding primary products like agricultural products, fuels, and mining products because they have relatively low demand elasticities that are too hard to explain with the gravity model.

Our dependent variable is manufacturing exports at US dollar with current prices is retrieved from WITS (2021). Basic gravity variables are economic sizes of Turkey and Eurozone countries, i.e. gross domestic products (GDPs) at US dollar with current prices and attained from World Development Indicators of World Bank (2021). Another basic gravity variable is the distance between country pairs which represents the transportation costs of trade which is taken from the CEPII database of Mayer and Zignago (2011). The model also includes two dummy variables which are usually given a place in augmented gravity model applications, i.e. common border and landlocked position, from the CEPII database of Mayer and Zignago (2011). The Linder effect is, following common application, represented with an absolute difference of per capita GDPs of Turkey and Eurozone countries that reflects the relative factor endowment differences between them. This variable is calculated by using the per capita GDPs at US dollar with current prices which are retrieved from World Development Indicators of World Bank (2021). Yet, there exists a much better indicator of the Linder effect, i.e. similarity index, is formulated by Helpman and Krugman (1985). The similarity index is shown as follows:

$$
S I M_{i j t}=\log \left[1-\left(\frac{G D P_{i t}}{G D P_{i t}+G D P_{j t}}\right)^{2}-\left(\frac{G D P_{j t}}{G D P_{i t}+G D P_{j t}}\right)^{2}\right]
$$

where i, j, and t signify the Turkey, Eurozone countries, and timespan, respectively. The similarity index ranges from 0 to 0.5 , and the value of 0 refers to economically exact divergence between country pairs, whereas the value of 0.5 indicates the exact convergence between them. This index is generated by using GDPs at US dollar with current prices which are taken from World Development Indicators of World Bank (2021).

Hereby, the bilateral export flows are functioned as in equation 2:

$$
\text { MANEXP }=f\left(G_{i}, G D P_{j}+\text { DIST }_{i j}, \text { CB }_{i j}, L_{j}, \text { RFED }_{i j}, S_{i M}\right)_{i j}
$$

All the variables except dummy ones were transformed to the natural logarithm. Herewith, the stochastic regression model is as follows:

$$
\begin{aligned}
& \operatorname{lnMANEXP}{ }_{\mathrm{ijt}}=\beta_{0}+\beta_{1} \operatorname{lnGDP}{ }_{\mathrm{it}}+\beta_{2} \operatorname{lnGDP}_{\mathrm{jt}}+\beta_{3} \operatorname{lnDIST} \mathrm{In}_{\mathrm{ij}}+\beta_{4} \mathrm{CB}_{\mathrm{ij}}+\beta_{5} \mathrm{LL}_{\mathrm{j}}+ \\
& \beta_{6} \operatorname{lnRFED} \mathrm{ijt}+\beta_{7} \ln \ln \mathrm{SIM}_{\mathrm{ijt}}+\mu_{\mathrm{ij}}+\lambda_{\mathrm{t}}+\mathrm{u}_{\mathrm{ijt}}
\end{aligned}
$$

In equation 3 , while $\mu, \lambda, \mathrm{u}$, and $\ln$ symbolize the unobservable country-specific (individual) effects, time effects, error term, and natural logarithm operator, respectively, $\beta(1, . .7)$ is the parameter coefficient to be estimated. While MANEXP $_{\mathrm{ijt}}$ shows the merchandise exports from Turkey to Eurozone countries, GDP $\mathrm{it}_{\mathrm{it}}$ and GDP $_{\mathrm{jt}}$ represent the economic sizes of Turkey and Eurozone countries, respectively. According to theoretical expectations, as the economic sizes of country pairs increase, bilateral trade flows would increase. Therefore, expected signs of both $\beta_{1}$ and $\beta_{2}$ are positive. Calculating by the great circle method, DIST $\mathrm{ij}_{\mathrm{ij}}$ represents the shortest physical distance between Istanbul and the trade centers of Eurozone countries individually. Since far distance means rising transportation costs, a negative association between distance and export flows is expected, $\beta 3<0$. The stimulating impact on manufacturing exports of $\mathrm{CB}_{\mathrm{ij}}$ referring to the existence of a common border between Turkey and Eurozone countries is expected, $\beta_{4}>0$. The landlocked position of Eurozone countries is a deterrent factor since it leads to increased transportation costs, $\beta_{5}<0$.

The variable of $\mathrm{RFED}_{\mathrm{ijt}}$ shows the difference of country pairs in terms of factor endowment, i.e. Linder effect. Since the country pairs would be more similar economically as the relative factor endowment difference decreases, according to the Linder hypothesis, $\beta_{6}$ should have a negative sign. In other words, a negative and statistically significant coefficient would mean the relevance of the Linder hypothesis. Additionally, the variable of SIM ijt symbolizing the similarity level of country pairs also represents the Linder effect. This variable may be evaluated as a check-up of the variable of relative factor endowment difference. So that the Linder hypothesis can be valid, the coefficient of $\beta_{7}$ should be in positive sign.

\section{Analysis and Results}

Before the econometric model of the study is estimated, the correlation relationship between variables was tested. When investigated the correlation coefficients presented in Table 3, it is observed that there is no multicollinearity problem in the model. 


\begin{tabular}{|c|c|c|c|c|c|c|c|c|}
\hline & $\exp _{\mathrm{ij}}$ & $\mathrm{gdp}_{\mathrm{i}}$ & $\mathrm{gdp}_{\mathrm{j}}$ & $\operatorname{dist}_{\mathrm{ij}}$ & $\mathrm{ll}_{\mathrm{j}}$ & $\mathrm{cb}_{\mathrm{ij}}$ & $\operatorname{rfed}_{\mathrm{ij}}$ & $\operatorname{sim}_{\mathrm{ij}}$ \\
\hline $\exp _{\mathrm{ij}}$ & 1.000 & & & & & & & \\
\hline $\mathrm{gdp}_{\mathrm{i}}$ & 0.187 & 1.000 & & & & & & \\
\hline $\mathrm{gdp}_{\mathrm{j}}$ & 0.806 & 0.121 & 1.000 & & & & & \\
\hline $\mathrm{dist}_{\mathrm{ij}}$ & 0.129 & 0.000 & 0.30 & 1.000 & & & & \\
\hline $\mathrm{ll}_{\mathrm{j}}$ & -0.277 & -0.000 & -0.1054 & -0.148 & 1.000 & & & \\
\hline $\mathrm{cb}_{\mathrm{ij}}$ & 0.091 & -0.000 & 0.044 & -0.603 & -0.102 & 1.000 & & \\
\hline $\mathrm{rfed}_{\mathrm{ij}}$ & 0.350 & 0.171 & 0.525 & 0.198 & 0.191 & -0.053 & 1.000 & \\
\hline $\operatorname{sim}_{\mathrm{ij}}$ & 0.575 & -0.038 & 0.832 & 0.283 & 0.057 & 0.172 & 0.501 & 1.000 \\
\hline
\end{tabular}

Table 3. Correlation Coefficients Between Variables

Panel data analysis which involves both time and cross-section dimensions is employed in the estimation process of the gravity model in equation 3 . In panel data analysis, the estimators like pooled OLS, fixed effects, and random effects are commonly used. Among these estimators, pooled OLS assumes the homogeneity of cross-sections, i.e. it ignores the country-specific effects, and estimates the model by pooling the data (Wooldridge, 2010). Therefore, pooled OLS doesn't usually yield unbiased and effective findings in the case of the existence of unobservable country-specific effects. The fixed effects estimator supposes the country-specific effects among cross-sections and models them as constant terms and then estimates a constant term for each cross-section. On the contrary, the random effects estimator behaves the country-specific effects as an error component and investigates whether error term components differ among cross-sections or time units. The choice between fixed effects and random effects is typically argued in the literature. While some arguments regarding this choice problem state that appropriate estimator of the econometric model can be determined based on prior information about the sample, other arguments depend upon more robustly some tests including redundant fixed effects test (the F-test), Lagrange multiplier test (the LM-tests), the Honda test, and correlated random effects test (the Hausman test) which may help select an appropriate estimator. Accordingly, if the F-test and LM-tests confirm the existence of countryspecific effects, in this case, what is the most important regarding the selection of an appropriate estimator depends on a base assumption. Accordingly, while the random effects estimator supposes that there is no relationship between unobservable country-specific effects and explanatory variables, the fixed effects estimator allows the relationship between them, i.e. endogeneity. The relationship between unobservable country-specific effects and explanatory variables is generally established by using the Hausman test.

Our prior tests indicate the existence of unobservable country-specific effects and refer to the fixed effects estimator as an appropriate estimator. Herewith, the gravity model in equation 3 was estimated with the fixed effects estimator and the results were presented in Table 4. Yet, one disadvantage of the fixed effects estimator is not to allow the estimation of time-invariant variables like common border, distance, and landlocked. Thus, equation 3 was also estimated by pooled OLS and random effects estimator, and the results were shown in Table 4. The estimation under alternative methods can help interpret the results comparatively and more healthfully. Overall, Table 4 involves the estimation findings of bilateral manufacturing exports under alternative estimators.

\begin{tabular}{|c|c|c|c|}
\hline Explanatory Variables & Pooled OLS & Fixed Effects & Random Effects \\
\hline $\mathrm{GDP}_{\mathrm{i}}$ & $0.322^{* *}(0.144)$ & $0.048(0.277)$ & $0.372^{* *}(0.153)$ \\
\hline $\mathrm{GDP}_{\mathrm{j}}$ & $0.994^{*}(0.063)$ & $1.686^{*}(0.563)$ & $0.832^{*}(0.136)$ \\
\hline $\mathrm{DIST}_{\mathrm{ij}}$ & $-0.802^{*}(0.191)$ & - & $-1.126^{* *}(0.476)$ \\
\hline $\mathrm{CB}_{\mathrm{ij}}$ & $-0.524(0.365)$ & - & $-1.125(0.904)$ \\
\hline $\mathrm{LL}_{\mathrm{j}}$ & $-0.974^{*}(0.171)$ & - & $-1.294^{*}(0.423)$ \\
\hline $\mathrm{RFED}_{\mathrm{ij}}$ & $-0.049(0.061)$ & $-0.058(0.205)$ & $0.105(0.109)$ \\
\hline $\mathrm{SIM}_{\mathrm{ij}}$ & $-0.284^{* *}(0.133)$ & $0.907^{* *}(0.393)$ & $0.103(0.264)$ \\
\hline Constant & $-15.147^{*}(4.041)$ & $-29.777^{*}(7.373)$ & $-10.679 *(5.014)$ \\
\hline & $\mathrm{F}(7,315)=121.24^{*}$ & $\mathrm{~F}(4,300)=21.54 *$ & $\mathrm{Wald} \mathrm{X}^{2}(7)=190.75^{*}$ \\
& $\mathrm{R}^{2}=0.729$ & $\mathrm{R}^{2}=0.611$ & $\mathrm{R}^{2}=0.715$ \\
\cline { 2 - 4 } & & Hausman Test $=12.47 * *$ \\
\hline
\end{tabular}

Table 4. Estimation Results of Bilateral Manufacturing Exports Note. * and ** imply the statistical significance at the levels of $1 \%$ and $5 \%$, respectively. The values in parenthesis are standard errors.

The findings of pooled OLS, fixed effects, and random effects estimators have a consensus on some determinants of bilateral manufacturing exports. Accordingly, the economic sizes of Eurozone countries are, as expected, the main driving force of Turkish manufacturing exports. However, the magnitude of coefficient estimated by fixed effects is higher than those of other estimators. As the economic sizes of these countries by $1 \%$ increase overall, Turkey's manufacturing exports increases by $1.686 \%$. This result draws attention to the importance of foreign 
demand for more manufacturing exports. According to the estimation of pooled OLS and random effects estimator, as a basic gravity variable, the distance between country pairs was, as expected, found to be a resistance factor against manufacturing exports. This finding shows that increasing distance between country pairs ends up with decreasing manufacturing export flows through increasing transportation costs. On the contrary the significant effect of distance, the effect of the common border on manufacturing exports was not found to be statistically significant. The landlocked position of Eurozone countries has a statistically significant and negative effect on manufacturing exports. Given the shipment by sea is cheaper compared with other transportation ways, this result seems compatible with theoretical expectations. According to the finding of the fixed effects estimator, the economic size of Turkey has not a statistically significant effect on manufacturing exports, albeit the pooled OLS and random effects estimator suggest its statistically significant and positive effect.

The findings regarding the Linder hypothesis from pooled OLS, fixed effects, and random effects estimators are much complicated. Pooled OLS, fixed effects, and random effects estimators put forward the statistically insignificant effect of relative factor endowment differences between country pairs on manufacturing exports. This result which is compatible with the findings of Işık (2015) means that the Linder hypothesis is not suitable for Turkey's manufacturing exports to Eurozone countries. On the other hand, similarity index and manufacturing exports were found to be statistically significant and associated negatively in pooled OLS estimation, whereas random effect estimator doesn't indicate its significant effect on manufacturing exports albeit its positive sign. However, here we focus on the findings of the fixed effects estimator since it is the best appropriate estimator for the econometric model of the study. Accordingly, there is a statistically significant and positive association between similarity index and manufacturing exports. The findings of the fixed effects estimator hang together, that is, the variables of relative factor endowment difference and similarity index have inverse signs, notwithstanding former is not statistically significant. Eventually, our results refer to the existence of the Linder effect in bilateral manufacturing exports from Turkey to Eurozone countries.

\section{Conclusion}

When the dominant and secular impact of traditional trade theories on international trade flows began to weaken, a few initiatives striving to substitute them took place at the beginning of the 1960s. Among these initiatives, Linder's (1961) argument colliding with traditional trade theories states that as countries converge to each other economically, trade intensity between them would go up. Linder's argument approaching demand-side to trade flows has been drawn attention and investigated empirically in most studies, especially given the most global trade flows were made among industrialized and economically similar countries. Besides, increasing share of intraindustry trade, increasing returns to scale, and more generally imperfect competition conditions in international trade led to gain the strength of Linder's argument, on the other hand, weakening traditional trade theories.

The study analyses the validity of the Linder hypothesis for bilateral manufacturing exports of Turkey to Eurozone countries in the framework of gravity model over the period of 2002-2018. In addition to the general implementation of modeling of the Linder effect, i.e. the usage of the absolute difference between per capita GDPs of country pairs, the study also employs the similarity index indicating to what extent the country pairs are similar to each other economically. Hereby, by using these two variables representing the Linder effect, the study aims to reach more robust findings regarding the validity of the Linder hypothesis. By doing this, the study also investigates the other determinants of bilateral manufacturing exports of Turkey to Eurozone countries.

The findings of the study show that the economic sizes of Eurozone countries and Turkish manufacturing exports are positively associated. Contrary to this, robust and significant evidence related to the impact of Turkey's economic size on its manufacturing exports was not found. While the common border effect was found to be statistically insignificant, the landlocked position of partner countries harms Turkey's manufacturing exports. Economically similarity of Turkey and Eurozone countries was found to be a driving force of manufacturing exports, albeit their difference in terms of relative factor endowment was statistically insignificant. Overall results refer to the existence of the Linder effect in bilateral manufacturing exports from Turkey to Eurozone countries. In other words, our results support Linder's argument and also refer to the importance of foreign demand in Turkey's manufacturing exports. Therefore, from the policy perspective, it is suggested that manufacturing exporters should monitor the course of consumer behaviors in Eurozone countries and adapt their product structures according to consumers' tastes and preferences to improve the export intensity.

\section{References}

- $\quad$ Akça, E. E., \& Bal, H. 2020. “Türkiye’nin İhracatında Linder Hipotezi’nin Geçerliliği Üzerine Ampirik Bir İnceleme: Genişletilmiş Çekim Modeli'nden Bulgular”, Yakın Doğu Üniversitesi Sosyal Bilimler Dergisi, 13(1), pp. 29-49.

- Arnon, A., \& Weinblatt, J. 1998. "Linder's Hypothesis Revisited: Income Similarity Effects for Low Income Countries", Applied Economics Letters, 5(10), pp. 607-611. 
- $\quad$ Atik, H. 2006. "Tercihlerde Benzerlik Teorisi: Türkiye ve Bazı Komşu Ülkelerin Dış Ticareti Üzerine Bir Analiz”, Ankara Üniversitesi SBF Dergisi, 61(02), pp. 33-43.

- Baldwin, R., \& Taglioni, D. 2006. "Gravity for Dummies and Dummies for Gravity Equations". NBER Working Paper, No: 12516, pp. 1-29.

- $\quad$ Bilgin, M. H., Demir, E., Lau, M. C. K., Kin-Man To, C., \& Zhang, Z. M. 2011. "The Turkish Handmade Carpet Industry: An Analysis in Comparison with Select Asian Countries", Journal of the Textile Institute, 102(6), pp. 514-526.

- Cebeci, H. İ., \& Ghorbani, S. 2020. "Integration of Bilateral Trade Between Turkey and Iran: An Application of Nonlinear Gravity Model”, International Journal of Management, 11(08), pp. 2019-2034.

- Çağlayan-Akay, E. \& Oskonbaeva, Z. 2017. "Uluslararası Ekonomik İşbirliği ve Kalkınma Teşkilatı Üye Ülkeleri için Linder Teorisinin Ampirik Bir Analizi”, In proceedings of International Conference on Eurasian Economies, pp. 161-167.

- Çağlayan-Akay, E. \& Oskonbaeva, Z. 2018. "Empirical Analysis of the Linder Hypothesis: A RandomEffects Tobit Model”, The Empirical Economics Letters, 17(1), pp. 87-97.

- Erkekoğlu, H., \& Arıç, K. H. 2013. "Statistical Analysis of the EU Countries and Turkey’s Competitiveness Dynamics and Some Assessments", International Research Journal of Finance and Economics, (109), pp. 88-99.

- $\quad$ Erkekoğlu, H., \& Yilmaz, B. 2019. "Investigation of Foreign Trade between Turkey and Member Countries of Asia-Pacific Economic Cooperation (APEC) with Gravity Model”, Journal of Yaşar University, 14(54), pp. 141-151.

- $\quad$ Gündüz, F. F., Özlem, Akay., Gündüz, S., \& Dölekoğlu, C. Ö. 2020. "Determination of The Factors Affecting Cotton Export of Turkey: A Panel Gravity Model Approach”, The Academic Elegance, 7(13), pp. 547-564.

- Hallak, J. C. 2004. "Product Quality, Linder, and the Direction of Trade", National Bureau of Economic Research, No. w10877, pp. 1-34.

- Helpman, E., \& Krugman, P. R. 1985. Market Structure and Foreign Trade: Increasing Returns, Imperfect Competition, and the International Economy, The MIT Press, London

- Işsk, N. 2015. “Avrupa Birliği-Türkiye Diş Ticaret Akımlarının Genişletilmiş Panel Çekim Modeliyle Tahmini”, Marmara Journal of European Studies, 23(1), pp. 49-67.

- Kohlhagen, S. W. 1977. "Income Distribution and" Representative Demand" In International Trade Flows: An Empirical Test of Linder's Hypothesis", Southern Economic Journal, 44(1), pp. 167-172.

- $\quad$ Linder, S. B. 1961. An Essay On Trade and Transformation. Almqvist \& Wiksell, Sweden: Uppsala.

- $\quad$ Maden, S. I., \& Aljburi, O. Q. A. 2019. "Türkiye ve Irak Arasindaki Diş Ticaretin Çekim Modeli İle Analizi”, Sosyal Bilimler Araştırmaları Dergisi, 14(1), pp. 229-262.

- Mayer, T., \& Zignago, S. 2011. "Notes on CEPII's distances measures: The GeoDist database”, Available online: https://papers.ssrn.com/sol3/papers.cfm?abstract_id=1994531.

- $\quad$ Saygili, F., \& Manavgat, G. 2014. "Linder Hipotezi: Türkiye'nin Dış Ticareti için Ampirik Bir Analiz", Ege Academic Review, 14(2), pp. 261-270.

- Tinbergen, J. 1962. Shaping the world economy: Suggestions for an international economic policy, The Twentieth Century Fund, New York.

- Yavuzaslan, K., Güder, M., İlknur, K., \& Kara, F. 2018. "Türkiye ve Yunanistan'ın İhracatında Linder Hipotezinin Etkisi: OECD Ülkeleri Üzerine Bir Analiz”, Aydın İktisat Fakültesi Dergisi, 3(1), pp. $48-67$.

- Yıldız, Ş., \& Künü, S. 2018. "Türkiye İle BRICS Ülkeleri Arasındaki Dış Ticaret Potansiyelinin Linder Hipotezi Çerçevesinde Değerlendirilmesi”, Kafkas Üniversitesi İktisadi ve İdari Bilimler Fakültesi Dergisi, 9(18), pp. 599-612.

- Wooldridge, J. M. 2010. Econometric Analysis of Cross Section and Panel Data. The MIT Press.

- UNCTAD, 2021. https://unctadstat.unctad.org/wds/ReportFolders/reportFolders.aspx.

- WITS, 2021. https://wits.worldbank.org/country-indicator.aspx?lang=en.

- World Bank 2021. https://databank.worldbank.org/source/world-development-indicators. 